\title{
Dispute on the Contract of Transferring Land-Use Rights: An Analysis of the Vietnamese Precedent No. 04/2016/AL
}

\section{Truong Thi Anh Nguyet*}

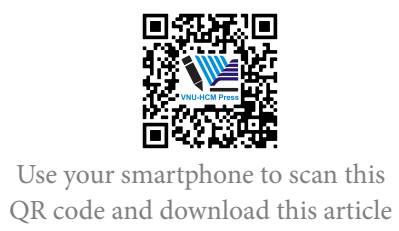

Faculty of Law, University of Economics, The University of Danang, Vietnam

\section{Correspondence}

Truong Thi Anh Nguyet, Faculty of Law, University of Economics, The University of Danang, Vietnam

Email: nguyettta@due.edu.vn

History

- Received: 01/10/2020

- Accepted: 26/02/2021

- Published: 31/03/2021

DOI : 10.32508/stdjelm.v5i1.702

\section{Check for updates}

\section{Copyright}

(.) VNU-HCM Press. This is an openaccess article distributed under the terms of the Creative Commons Attribution 4.0 International license.

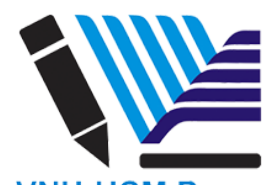

VNU-HCM Press

\begin{abstract}
Among many precedents involving the land issue, the precedent No. 04/2016/AL regulates the dispute on the contract for transferring land-use rights. Passed by The Council of Judges of The Supreme People's Court on April 6, 2016, house ownership and land-use rights are marital properties, but only the husband or the wife signs the contract on selling the house and transferring the land-use rights to another, and the transferor received the full payment from the transferee as agreed. The husband or the wife did not sign the contract. If there is sufficient evidence supporting that: (i) this person knows the transfer and jointly uses the money paid from transferring the landuse rights; and (ii) this person knows that the transferee received, managed and used this house and land publicly without having any objections. In this case, it is necessary to determine that person agreed upon with the transfer of land-use rights. Despite its significance and role in the dynamics of the Vietnamese law, little research has been conducted into the extent to which the precedent has a considerable impact on the application of local courts. Furthermore, the understanding and analysis of precedents have not been fully explored. The article aims to analyze the controversial points that focus on an unwritten consent in the aforementioned transaction. This paper examines the legal and practical values of precedent - as a guideline - in three striking aspects: (i) applying precedent to settle cases containing similar issues; (ii) filling a gap in a transaction with the third party of the marital property but only the spouse signed the contract; and (iii) extending the scope of the jointly marital ownership to include the range of common property of households' members. The exploration of this precedent, thus, contributes to the understanding of the contemporary socialist law and the comprehensively legal framework for the precedent system in Vietnam.

Key words: Vietnamese precedents, Precedent No. 04/2016/AL, the contract of transferring land use-rights, marital properties
\end{abstract}

\section{INTRODUCTION}

A precedent is defined as the arguments and rulings in a legally effective judgment or decision (hereinafter referred to as "judgment") of the courts that are selected by the Council of Justices of the Supreme People's Court and published by the Chief Justice of the Supreme People's Court in order for other courts to study and apply them when deciding later cases [ ${ }^{1}$, art. 1]. The creation and adoption of Vietnamese precedents contribute to the dynamics of the contemporary socialist law $\left[{ }^{2}, \mathrm{p}\right.$. 5]. This precedent is passed by The Council of Judges of The Supreme People's Court on April 6, 2016 and announced in accordance with the Decision No. 220/QD-CA dated April 6, 2016 of the Chief Justice of the Supreme People's Court. The essential content of the precedent is summarized as follows.

The house ownership and land-use rights are the marital properties, but only husband or wife (The seller or the transferor) sign the contract on selling the house and transferring the land-use rights to another (The buyer or the transferee), and the transferor received the full payment from the transferee as agreed. The husband or wife who did not sign the contract; however, there is sufficient evidence to determine: (i) this person knows the transfer and jointly uses the money paid from transferring the land-use rights; and (ii) this person knows about the fact that the transferee received, managed and used of this house and land publicly without having any objections. In this case, it is necessary to judge that person agreed upon with the transfer of land-use rights.

The article aims to analyze the controversial points focusing on an unwritten consent in the aforementioned transaction. This paper examines the legal and practical values of precedent in three striking aspects: (i) applying precedent to settle cases containing similar issues; (ii) filling a gap in an issue of marital property in the transaction with the third party but only the spouse signed the contract; and (iii) extending the scope of the jointly marital ownership in the precedent to include the range of common property 
of households' members. This study makes a valuable contribution to the existing scholarship.

\section{LITERATURE REVIEW}

Among the published precedents, the precedent No. 04/2016/AL on the case of "dispute on the contract of transferring land-use rights" contains significant legal value and practical application. In practice, when applying legal provisions on disposition of common property of the husband and wife, some difficulties may arise if a spouse established a transaction without the consent of the remainder. The precedent No. 04/2016/AL is a typical example in this case.

Regarding the precedent No. 04/2016/AL, there do not have many articles that analyze and comment on its content and legal value. Recently, Do Van Dai and Ngo Thi Anh Van published an article entitled "Regarding the consent of the subject in civil transactions" in the Vietnamese Journal of Legal Sciences, No. 01(113)/2018. By using qualitative analysis, these authors researched and commented on the impact of the precedent in determining the consent of joint owners to the validity of a civil transaction. The aforementioned article addressed in part the issue of the precedent's impacts on the transaction formality. However, the legal and practical values that go beyond the application of the precedent have not been fully explored. It is therefore necessary to conduct an indepth analysis of precedent.

\section{RESEARCH OBJECTIVES AND METHODOLOGY}

The article aims to examine the will of a spouse who did not sign the contract stipulated between the transferor and the transferee. It also evaluates about the legal and practical values of precedents in three remarkable aspects, which will pave the way for analyzing systematically and comprehensively about the Vietnamese precedents.

Qualitative analysis is mainly used in the research, which explores the legal and practical values of the precedent in striking points. In addition, the research adopts case-based data collection, the synthesis method and first-hand analysis.

\section{RESULTS AND DISCUSSION}

\section{Fact and the Supreme Court's Opinions: A General Evaluation}

The case can be briefly described as follows.

In 1996, Mrs. Ty and her husband-Mr. Tien (the buyer and the transferee simultaneously) bought two 4-storey houses on the residential land adjacent to
X.L. Street of the couple Mr. Ngu and Mrs. Phan (the seller and the transferor simultaneously) at X.L. Ward, T.H District, Hanoi. Both parties signed the contract to transfer the houses and the land-use rights. Since Mrs. Ty and her husband did not have permanent residence in Hanoi, the local authorities did not grant a certificate of land-use rights and house ownership to them. Mrs. Ty and her husband paid full money (110 "cây vàng": the unit of gold in Vietnam), received the house and land-use rights. Then the dispute over the contract for transferring the land-use rights and house ownership arose between two parties. At that time, the contract was owned by Mr. Ngu and Mrs. Phan. On October 29, 2007, Mrs. Ty and Mr. Tien sued for the house ownership and land-use rights through the aforementioned contract. At the same time, the entire previous house ownership and land-use rights had to return. Ms. Ty and Mr. Tien asked Mr. Ngu and Mrs. Phan to remove the illegal construction on the mentioned land.

On May 08, 2008, Mr. Ngu and Mrs. Phan appealed to the Court of Appeal for a request to rescind the contract signed with Mrs. Ty and Mr. Tien. The given reason was that the signing of the contract and the payment thereof were carried out by Mr. Ngu only, while his wife (Mrs. Phan) was unknown. After the appeal trial, Mrs. Phan argued that the house ownership and land-use rights at No. 39 X.L. Street was the marital properties. However, Mr. Ngu intentionally sold these properties to Mrs. Ty and Mr. Tien without the consent of Mrs. Phan. Mrs. Phan thus denied the contract's legality and made a request from the Supreme Court for an invalid contract.

Whether the transfer of the land doing by Mr. Ngu with Mrs. Ty and Mr. Tien, was approved by Mrs. Phan or not? Regarding this case, the viewpoint of the Supreme Court was expressed as follows.

The testimonies from the children of Mr. Ngu showed that after selling the houses and transferring the landuse rights for Mrs. Ty, Mr. Ngu and Mrs. Phan distributed publicly the gold benefited from the transaction for them. After transferring and delivering houses and transferring the land-use rights to Mrs. Ty, Mr. Ngu wrote a "letter of undertaking" with its content that he borrowed the part of the transferred land to stay, and in fact, Mr. Ngu and Mrs. Phan used this land. Therefore, the Supreme Court found that there was a legal basis for determining that Mrs. Phan knew about transferring the land-use rights between Mr. Ngu and Mrs. Ty, then Mrs. Phan agreed and conducted the transaction jointly. For these reasons, Mrs. Phan's appeal was rejected. 
At the time of the stated case, the Vietnamese Civil Code 1995 and Law on Marriage and Family 1986 were applied. The crux of the matter lies in Article 176 Clause 2 of the former document and Article 15 of the latter. Specifically, Law on Marriage and Family 1986 stipulates that the transaction relating to the marital property, provided that its value is significant, must be agreed upon by both the husband and wife. From the aspect of the transferee in this case, on the other hand, the house ownership of the transferee is established because of the agreed transfer of ownership between the transferor and the transferee through the contract.

In assessing the judgment of the Supreme Court in this precedent, some key points are raised from the perspective of the author.

The court invoked two provisions in this precedent, namely Article 176 of the 1995 Vietnamese Civil Code and Article 15 of the 1986 Law on Marriage and Family, but the correlations between the facts in the precedent and these two provisions are not explicitly analyzed in the court's judgment. The author assumes that this gap should be filled by providing an explanation of the relevant facts and invoked provisions. Put more clearly, Article 176 of the 1995 Vietnamese Civil Code stated that the ownership right shall be established in the case of transferring the ownership right as agreed between the parties or according to the decision of the competent authority. This provision proves the content part of the precedent: Mr. Ngu signed the contract of elling the houses and transferring the land-use rights to Mrs. Ty and Mr. Tien (The buyer and the transferee), thus the ownership right is established to the latter party. Meanwhile, Article 15 of the 1986 Law on Marriage and Family stipulates that the transaction relating to the marital property, provided that its value is significant, must be agreed upon by both the husband and wife. The content of this provision is directly related to the conflict between Mr. Ngu and Mrs. Phan.

\section{The Debatable Points Focus on an Unwrit- ten Consent}

The focal point of this precedent emphasizes the consent of a spouse who did not sign the contract established between the transferor and the transferee. Regarding this issue, two essential requirements must be met:

Firstly, this person must know the transaction conducted by his or her spouse. Apparently, this originates from two points. The first thing is that the common ownership by husband and wife is common ownership by integration [ ${ }^{3}$, art. 233(1)], thus, joint owners shall have equal rights to possess, use, and dispose of such property [ ${ }^{3}$, art. 233(2)]. The Civil Code respects the agreement or authorization between husband and wife in relation to the possession, use and disposal of the marital property [3, art. 233(3)].

The judgment of the Supreme Court has no expression of what form of agreement between Mrs. Phan and her husband to dispose of their valued property. In this regard, the court applied Article 15 of the 1986 Vietnamese Law on Marriage and Family. More specifically, the sale [...] and other transactions relating to property that is of great value must be agreed upon by the husband and wife [ ${ }^{4}$, art. 15]. Since the agreement in writing was not required in the 1986 Vietnamese Law on Marriage and Family, the agreement in verbal or behaviour form can be accepted. Neither verbal agreement nor objections were raised by Mrs. Phan in the case. On the one hand, while stipulating the mutual agreement is the requisite of establishing the transactions relating to marital property, the lack of regulations on the form of the agreement and the valuation of the kinds of marital property considered as considerably valued one, are the gaps in the 1986 Law on Marriage and Family, on the other hand. Currently, the 2014 Law on Marriage and Family contributes to fill the foregoing gaps by stating that the disposition of the following common property shall be agreed in writing by husband and wife : (a) Real estate; (b) Movable assets which are required by law to be registered for ownership; (c) Assets which are the major income-generating source for the family $\left[{ }^{5}\right.$, art. 35(2)].

Secondly, this person did not object to any transactions that took place. Assuming that Mrs. Phan knew the mentioned transaction, but she did not initially consent to her husband to sign the contract. Regardless of this, her husband still signed the contract with Mrs. Ty and Mr. Tien. Mrs. Phan did not express any objections to her husband's act, meaning the implicit silence. For the Supreme Court, Mrs. Phan's silence is recognized in this precedent as implicit consent. Evaluating the Legal and Practical Values of Precedent: Remarkable Points

\section{A Model for Application of Cases Contain- ing Similar Issues}

It is known that the Vietnamese Precedent No. 04/2016/AL on dispute over the contract for transferring land-use rights is the model for applying the principles of this precedent and Civil law in civil cases that contain similar factors.

In the precedent, it is important to determine that the common ownership by husband and wife when conducting the transaction must be agreed upon by both. 
More importantly, if there is no written agreement between the husband and wife, this precedent will solve the important knot in terms of the validity of the contract on transferring the land-use rights exercised by the spouse. In this case, the spouse knew the occurred transaction, but raised no objections. The fact is that the precedent No. 04/2016/AL serves as a guideline for many local courts to apply it. Currently, about 13 cases applied this precedent ${ }^{6}$, although the confusion and difficulties in determining the similar elements are unavoidable. This section analyzes how similar elements are used based on the spirit of the foregoing precedent.

(a) The judgment No.198/2017/DS-PT dated August 22, 2017 ${ }^{7}$ : An original application of the precedent No. 04/2016/AL. In this case, one spouse at first knew that a transaction related to the transfer of land-use rights taken place, but this person did not object.

This judgment relates to the case with its name "dispute with the contract on exchange of land-use rights" (“Tranh chấp hợp đồng chuyển đổi quyền sử dụng đất"), which was passed by the High People Court in Ho Chi Minh City. It involves a series of land-use rights transactions. However, the factors relate to the invocation of the Precedent No. 04/2016/AL, which was analyzed in this section.

The fact of this case could be briefly described as follows. X (husband) and T (wife) had the joint ownerships of the land-use rights. X unilaterally wrote "Undertakings to transfer land" ("Giấy giao đất") to $\mathrm{P}$. $\mathrm{T}$ and their child did know this transaction at that time. $\mathrm{T}$ sued the court for declaring the "Paper on land allocation" invalid.

The Judicial Council of the High Court assesses that the legal nature and circumstances in this case are similar to those of the Precedent No. 04/2016/AL. Mrs. T and her children did not sign the "Undertakings to transfer land". However, they knew that Mr. $\mathrm{X}$ transferred the land-use rights and did not protest against that transaction. They also received the payment from transferring of the land-use rights. From these arguments and application on the precedent No. 04/2016/AL, it is reasonable to conclude $\mathrm{T}$ and her children knew and agreed with $\mathrm{X}$ to transfer the landuse rights to $\mathrm{P}$. Therefore, the court did not accept the whole petition of $\mathrm{T}$ against $\mathrm{X}$ on request to rescind the contract between $\mathrm{X}$ and $\mathrm{P}$.

(b) The judgment No. 135/2016/DS-PT dated July 08, 2016 ${ }^{8}$ : An extension of the precedent No. 04/2016/AL. Notably, the relevant parties were the members of a household, they initially did not know the happening of transaction, but they were known and announced after completing that transaction.
This judgment relates to the dispute over the land-use rights; the rights to ask for housing; house purchase contract and request to rescind the certificate on landuse rights, which was passed by the People Court of Hau Giang Province. Within the scope of this section, only the parts of the dispute concerning the Precedent No. 04/2016/AL are analyzed.

The fact refers to the application of the precedent No. 04/2016/AL that could be briefly described as follows. Mrs. Phấn (the wife) and Mr. Thuân (the husband) were the co-owners of the land-use rights (including the rights on the disputed land, an area of $11.380 \mathrm{~m}^{2}$ of the garden and field land) and the ownership rights on a house located in land No. 55, Thi Tu hamlet, Rach Goi town, Chau Thanh A district, Hau Giang province (hereafter the house No. 55). They had eight children, namely Thuấn, Thúy, Thanh, Thảo, Thẩm, Thường, Thủy and Thùy. After Mr. Thuần died, Mrs. Phấn acted as the owner of the mentioned properties formally ("Sau khi ông Thuần chết, các tài sản đã được đề cập do bà Phấn đứng tên"). On June 1, 2005, Mrs. Phấn and her children agreed that the aforementioned properties would be divided equally into nine parts, one part owned by Mrs. Phấn and eight parts owned by eight children, each person owned partially. On June 10, 2007, Mrs. Phấn and her six children (Thuấn and Thẩm were absent) who were present at the family gathering signed in a document to give their consent to sell the house No. 55 to Thủy at hand. On July 23, 2007, Mrs. Phan established the contract to give the land-use rights in the residential land at the house No. 55 ("phân đất thổ cư tại số nhà 55") to Thủy as a gift, and then Thủy was granted a certificate No. H00087 of land-use rights.

At the appellate court, Thuấn and Thẩm testified that they did not know about the house-related transaction as mentioned. They were then announced by another members of their family after completing transaction, but they showed no objections. Moreover, while Thủy used the house and repaired it publicly, Thuấn and Thẩm had no objections. Based on their testimony, it was reasonable to determine that Thuấn and Thẩm knew the transaction between Mrs. Phấn and Thủy. By applying the precedent No. 04/2016/AL, the court recognized the legality of purchasing and using the house that were conducted by Thủy.

The viewpoints of Court of Appeal were shown in the judgment No. 135/2016/DS-PT dated July 08, 2016 as follows: (i) the land-use rights and house-ownership were the common properties of Mrs. Phấn and her eight children; (ii) Mrs. Phấn and her six children among eight children agreed to transfer the aforementioned rights to Thủy; and (iii) Thủy used the land and 
house stably, built, repaired and renewed the house. Thus, it should be stable for Thủy to continue using. Thuấn and Thẩm knew the transaction between Mrs. Phấn and Thủy after its completion, but they did not object. Thuấn and Thẩm did not receive the corresponding amount of money that benefited from the sale of house No. 55. Hence, it was reasonable to require Thủy to pay the part of the value benefited from selling the house and the land-use rights to Thuấn and Thẩm. According to the agreement of the litigants, the house and land-use rights in 2007 were priced at $1,300,000,000$ VND. These properties belonged to the ownership of nine people, each person was owned $144,444,444$ VND. In this case, Thủy was responsible for paying Thuấn and Thẩm, $144,444,444 \mathrm{VND}$ for each.

As can be seen, the precedent No. 04/2016/AL was applied to include the common property of households' members, or property of family members living together. In the 2015 Civil Code, its Article 212(1) defines that "Property of family members living together includes property that they contributed or made together and other properties whose ownership rights are established in accordance with this Code and relevant laws" [ ${ }^{9}$, art. 212(1)]. Mrs. Phấn in the above case acted as the representative authorized of the common property of a household, which conformed to Article 101(1) of the 2015 Civil Code [ ${ }^{9}$, art. 101(1)]. Initially, there was an agreement between seven family members of household involving the division of the common property into nine parts equally. This was applied from Article 212(2) of the 2015 Civil Code, which states that the disposition of an immovable property, e.g. land or house, the agreement between all family members being adults with full legal capacity is required, unless otherwise prescribed by law $\left[{ }^{9}\right.$, art. 212(2)].

The sale of the house No. 55 to Thủy lacked of the agreement of two among nine family members, the regulations on ownership in common ("sở hữu chung theo phân”) were applied [ ${ }^{9}$, art. 212(2)]. Article 217(1) of the 2015 Civil Code stipulates that: "Each owner in common has the right to exploit, and to enjoy the yield and income derived from, the multiple ownership property in proportion to its share of the ownership rights, unless otherwise agreed or otherwise provided by law" [ ${ }^{9}$, art. $\left.217(1)\right]$. In this regard, Thuấn and Thẩm each had the right to enjoy $144,444,444$ VND that was in proportion to its share of the ownership rights benefited from selling the house and the land-use rights.

The precedent No. 04/2016/AL supports the standpoint involving the "silent party" in the transaction that is the similarity of precedent and the judgment No. 135/2016/DS-PT. In the precedent, the "silent party" refers to the person who did not sign the contract but knew the transaction. Meanwhile, the "silent party" in the judgment No. 135/2016/DS-PT implies that the person did not know about and take part in as a party in the mentioned transaction. However, the "silent party" knew the transaction after its completion and they showed no objections. Another similarity between precedent No. 04/2016/AL and judgment No. $135 / 2016 /$ DS-PT is that the agreement between husband and wife in the former and the agreement of all family members in the latter were not required to be shown in the written documents. More specifically, it was the party's will of "know" about the existence of transaction (which happened previously, concurrently with, or after the transaction), albeit a lack of written forms and without objection by this party that shows the party's implicit consent. Generally, the precedent No. 04/2016/AL clarifies that the consent can be given at any time and not necessarily manifested in the same document recorded the agreement with the purchaser or transferee [ ${ }^{10}$, p. 74]. Regarding the act of receiving money, it was conducted by the "silent party" in the precedent No. 04/2016/AL, but it was not happen in the judgment No. 135/2016/DS-PT. However, the acts of receiving money in both cases are a consequence of disposition of their co-owned property.

\section{Marital Property in the transaction with The Third Party but only The Spouse Signed The Contract: Filling A Gap}

Before the publication of precedent No. 04/2016/AL, there were many cases in practice involving the marital property in the transaction with the third party. In the transactions relating to the common property whose value is significant, the agreement between the husband and the wife was required. This was based on applying the Law on Marriage and Family version 2000 and version $2014^{10}$. In this regard, Article 28(3) of the 2000 Law on Marriage and Family provides that the acts of establishing, making and terminating civil transactions relating to the common property whose value is significant or the sole source of the family, the use of common property to invest in business must be discussed and agreed by both husband and wife [ ${ }^{11}$, art. 28(3)]. Furthermore, the establishment, making and termination of transactions related to the home being the sole domicile of husband and wife shall be agreed by both of them, which was found in Article 31 of the 2014 Law on Marriage and Family [ ${ }^{5}$, art. 
31]. Moreover, Article 35(2)(a) of this law stipulates that the agreement in writing between husband and wife was required $\left[{ }^{5}\right.$, art. $\left.35(2)(\mathrm{a})\right]$. In this case, if the precedent No. 04/2016/AL was not promulgated, the contract of transferring land-use rights between $\mathrm{Mr}$. Ngu and Mrs. Ty would be invalid due to the lack of agreement in writing by Mrs. Phan. In other words, the precedent No. 04/2016/AL deviates from the written consent requirement under the 2014 Law on Marriage and Family, which give another insight into the spouse's transaction with the third party.

In many cases, one of the spouses sue the court to claim the invalid contract of transferring land-use rights. This stems from the fact that the claimant did not sign the contract involving the transaction conducted by his/her wife/husband with the third party. The precedent No. 04/2016/AL helps to "loosen a knot" that existed in practice. The insistence on the requirement of the signatures of husband and wife in the aforemention contract seems to be rigid, together with the failure to keep up the practical facts ${ }^{10}$. The precedent shows its flexibility in resolving the contract involving the common property of the husband and wife with the third party, but only husband or wife signed. The evidence to prove those who did not sign the contract but know this transaction is required.

From the Jointly Marital Ownership to the Common Property of Households' Members: A Striking Extension

One salient point of the Precedent No. 04/2016/AL is its contribution to the extension of the scope applied in practice. The original legal nature of the precedent is the dispute that involves the contract for transferring land-use rights. In this dispute, the landuse rights are the common properties of husband and wife. Beyond the Supreme Court's judgment, however, the practice has shown in some cases that the common property of household's members could invoke the principle of the Precedent No. 04/2016/AL.

(a) A group of cases applying the precedent No. 04/2016/AL

According to unofficial statistics in 2018, at least 13 cases in local courts ${ }^{6}$ have applied the precedent No. 04/2016/AL. Some examples of these cases, including the judgment No. 29/2017/DS-PT dated December 20, 2017 of the People's court of Quang Binh Province related to request to declare the transfer of landuse rights invalid; the judgment No. 198/2017/DSPT dated August 22, 2018 of the High-level People's Court in Ho Chi Minh City; the judgment No. 40/2017/DS-PT dated September 19, 2017 of the People's court of Vinh Phuc Province; the judgment No.
122/2017/DS-PT dated July 04, 2017 of the People's court of Hau Giang Province concerning to dispute with contract on transfer of land-use rights the judgment No. 03/2018/HNGĐ-PT dated January 26, 2018 of the People's Court of Binh Phuoc Province related to the dispute with dividing the common property.

(b) An indirect application of the precedent No. 04/2016/AL to judgment 144/2018/DS-PT: Answering the question of ownership of the common property of households' members.

The judgment No. 144/2018/DS-PT dated April 02, 2018 on the dispute relating to the contract for the transfer of land-use rights and the request for revocation of the certificate of land-use rights. This judgment was passed by Tien Giang Province People's Court. This case could be summarized as follows.

The land $\mathrm{X}$, with its land-use rights are the common property of H's household members, including 4 people: B, H, T.P and C.P. In 2002, B unilaterally sold this land to $\mathrm{T}$ without the consent of H, T.P and C.P. At the time of signing the contract on transferring the landuse rights between $\mathrm{B}$ and T, three people (H, T.P, and C.P) did not know this transaction. Thus, $\mathrm{H}$ requested the court to claim this contract was invalid and revoke the certificate on land-use rights issued by the local government to T. Regarding this case, the court ruled that the nature of this case was the contract on transferring the land-use rights between $\mathrm{B}$ and T. After the transfer of land-use rights, $\mathrm{T}$ paid full money for $\mathrm{B}$. Hence, $\mathrm{T}$ had the right to use that land. Meanwhile, H, C.P, and T.P lived together with B on the remaining land which was adjacent to the land transferred to Mr. T.

According to the Precedent No. 04/2016/AL, the Court argued: B received the full amount of money as agreed with T. Simultaneously, T received, managed and used that land publicly. In the transaction between $\mathrm{B}$ and $\mathrm{T}$, although $\mathrm{H}$ did not sign the contract, $\mathrm{H}$ obviously knew that $\mathrm{B}$ transferred the foregoing land to T. Furthermore, $\mathrm{H}$ did not show any objections. It thus was reasonable to determine that $\mathrm{H}$ agreed with the transfer made by B. The court argued that the land had been allocated to four people of the household, and B represented for household members in the certificate on land-use rights. B voluntarily transferred the land-use rights to $\mathrm{T}$, thus it did not affect the interests of other household members. Moreover, all members of a household agree to authorize to enter into and transfer the land-use rights that were their common property [ ${ }^{9}$, art. 138(2)]. For these reasons, the People's Court of Tien Giang Province rejected the petition of $\mathrm{H}$. 
It can be seen that the judgment No. 144/2018/DS$\mathrm{PT}$ is a typical example of applying the precedent No. $04 / 2016 / \mathrm{AL}$ in solving a dispute over common property of household members. In other words, the precedent No. 04/2016/AL extends its scope from the original case of jointly marital ownership to the multiple ownership property.

\section{CONCLUSION}

This article provides an insight into the precedent No. 04/2016/AL which involves dispute on the contract of transferring land use right. The legal issue of the precedent is that the house ownership and the landuse rights are the marital properties. However, only husband or wife sign the contract on selling the house and transferring the land-use rights to another. The transferor received the full payment from the transferee. Although the husband or wife did not sign the contract, if there is sufficient evidence to determine: (i) this person knows the transfer and jointly uses the money paid from transferring the land-use rights; and (ii) this person knows about the fact that the transferee received, managed and used of this house and land publicly without having any objections, it can be concluded this person agreed upon with the transfer of land-use rights.

The correlation between the facts in the precedent and relevant provisions has not explicitly analyzed in the Supreme Court's judgment. This gap should be filled by providing an explanation of the facts and invoked provisions. The article examines the legal and practical values of precedent - as a guideline - in three striking aspects: (i) applying precedent to settle cases containing similar issues; (ii) filling a gap in an issue of marital property in the transaction with the third party but only the spouse signed the contract; and (iii) extending the scope of the jointly marital ownership in the precedent to include the range of common property of households' members. Analyzing this precedent contributes to understanding the dynamics of the contemporary socialist law and the comprehensive legal framework for the precedent system in Vietnam.

\section{ACKNOWLEDGEMENTS}

This research is funded by University of Economics - The University of Danang under project number T2021-04-14.

\section{CONFLICTS OF INTEREST}

The author declares that there have no conflicts of interest in the article.

\section{AUTHOR'S CONTRIBUTION}

All the contents of the article is done by the sole author.

\section{REFERENCES}

1. Resolution No. 04/2019/NQ-HDTP of The Council of Justices of The Supreme People's Court on Process for Selecting, Pulishing and Applying Precedents. 2019;.

2. Bui NS. The Socialist Precedent, Cornell International Law Journal. 2019;52(3):421-474.

3. The National Assembly. The 1995 Vietnamese Civil Code, Hanoi. 1995;

4. The National Assembly. The 1986 Vietnamese Law on Marriage and Family, Hanoi. 1986;

5. The National Assembly. The 2014 Vietnamese Law on Marriage and Family, Hanoi. 2014;

6. Hue K. 13 judgments apply the precedent No. 04/2016/AL on disputes with the contracts on transferring land-use rights (13 bản án áp dụng Án lệ 04/2016/AL về tranh chấp hợp đồng chuyển nhượng quyền sử dụng đất). [cited 2021 January 10];Available from: https://thuvienphapluat.vn/banan/tintuc/13-ban- an-ap-dung-an-le-042016al-ve-tranh-chap-hopdong-chuyen-nhuong-quyen-su-dung-dat- 50.

7. The Case No. 198/2017/DS-PT dated August 22, 2017 on Dispute on the Contract of Exchanging Land-Use Rights ("Bản án 198/2017/DS-PT ngày 22/08/2017 về tranh chấp hợp đồng chuyển đổi quyền sử dụng đất"). [cited 2021 January 10];Available from: https://banan.thuvienphapluat.vn/banan/ban-an- $1982017 \mathrm{dspt}$-ngay-22082017-ve-tranh-chap-hopdong-chuyen-doi- quyen-su-dung-dat- 24958.

8. The Case No. 135/2016/DS-PT dated July 08, 2016 on Dispute on the Land-Use Rights; Asking for a House for Stay; Sales Contracts of Houses and Request to Cancel the Certificate of Land-Use Rights ("Bản án 135/2016/DS-PT ngày 08/07/2016 về việc tranh chấp quyền sử dụng đất; đòi nhà cho ở nhờ; hợp đồng mua bán nhà ở và yêu cầu hủy giấy chứng nhận quyền sử dụng đất"). [cited 2021 January 10];Available from: https://thuvienphapluat.vn/banan/ban-an/ban-an1352016dspt-ngay-08072016-ve-viec-tranh-chap-quyen-sudung-dat-doi-nha-cho-o-nho-hop-d-1293.

9. The National Assembly. The 2015 Vietnamese Civil Code, Hanoi. 2015;.

10. Dai DV, Van NTA. Regarding the Consent of the Subject in Civil Transactions ("Về sự ưng thuận của chủ thể trong giao dịch dân sự"). Vietnamese Journal of Legal Sciences (Tạp chí Khoa học Pháp lý Việt Nam). 2018;01(113).

11. The National Assembly. The 2000 Vietnamese Law on Marriage and Family, Hanoi. 2000; 


\section{Tranh chấp hợp đồng chuyển nhượng quyền sử dụng đất: Phân tích từ án lệ số 04/2016/AL}

\section{Trương Thị Ánh Nguyệt}

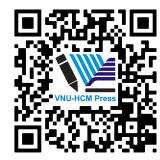

Use your smartphone to scan this QR code and download this article

\section{TÓM TẮT}

Trong số các án lệ liên quan đến đất đai, án lệ số 04/2016/AL (được Hội đồng Thẩm phán Tòa án nhân dân tối cao thông qua ngày 06 tháng 4 năm 2016) quy định về tranh chấp hợp đông chuyển nhượng quyền sử dụng đất. Án lệ này đề cập đến vấn để pháp lý, đó là: Trường hợp nhà đất là tài sản chung của vợ chông mà chỉ có một người đứng tên ký hợp đồng chuyển nhượng nhà đất đó cho người khác, người còn lại không ký tên trong hợp đồng; nểu có đủ căn cứ xác định bên chuyển nhượng đã nhận đủ số tiên theo thỏa thuận, người không ký tên trong hợp đông biết và cùng sử dụng tiền chuyển nhượng nhà đất; bên nhận chuyển nhượng nhà đất đã nhận và quản lý, sử dụng nhà đất đó công khai; người không ký tên trong hợp đồng biết mà không có ý kiến phản đối gì thì phải xác định là người đó đồng ý với việc chuyển nhượng nhà đất. Mặc dù tầm quan trọng và vai trò của án lệ này trong sự phát triển của pháp luật Việt Nam, rất ít nghiển cứu được tiến hành trong phạm vi mà ở đó án lệ có sự ảnh hưởng đáng kể đến việc vận dụng án lệ ở các tòa án địa phương. Ngoài ra, sự hiểu và phân tích vê án lệ vẫn chưa được khám phá đây đủ. Bài báo nhằm mục đích phân tích các điểm gây tranh cãi tập trung vào ý chí của người vắng mặt trong giao dịch nói trên. Bài báo này xem xét các giá trị pháp lý và thực tiễn của án lệ - như là một kim chỉ nam - trên ba khía cạnh nổi bật: (i) áp dụng án lệ để giải quyết các vụ án chứa các vấn đề tương tự; (ii) lấp khoảng trống trong vấn để tài sản hôn nhân trong giao dịch với bên thứ ba mà chỉ có vợ hoặc chồng ký hợp đồng; và (iii) mở rộng phạm vi sở hữu chung trong hôn nhân trong án lệ để bao gồm cả phạm vi tài sản chung của các thành viên trong hộ gia đỉnh. Phân tích án lệ này đóng góp vào việc tìm hiểu về sự phát triển của pháp luật xã hội chủ nghĩa đương đại và khung pháp lý toàn diện cho hệ thống án lệ ở Việt Nam.

Từ khoá: Án lệ Việt Nam, án lệ số 04/2016/AL, hợp đồng chuyển nhượng quyền sử dụng đất, tài sản chung của vợ chông
Khoa Luật - Trường Đai học Kinh tế Đại học Đà Nẵng; Việt Nam

\section{Liên hệ}

Trương Thị Ánh Nguyệt, Khoa Luật - Trường Đại học Kinh tế - Đại học Đà Nẵng; Việt Nam

Email: nguyettta@due.edu.vn

Lịch sử

- Ngày nhận: 01/10/2020

- Ngày chấp nhận: 26/02/2021

- Ngày đăng: 31/03/2021

DOI : 10.32508/stdjelm.v5i1.702

\section{Check for updates}

\section{Bản quyền}

๑ ĐHQG Tp.HCM. Đây là bài báo công bố mở được phát hành theo các điều khoản của the Creative Commons Attribution 4.0 International license.

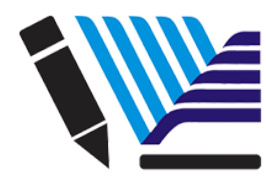

VNU-HCM Press
Trích dẫn bài báo này: Nguyệt T T A. Tranh chấp hợp đồng chuyển nhượng quyền sử dụng đất: Phân tích từ án lệ số 04/2016/AL. Sci. Tech. Dev. J. - ECo. Law Manag.; 5(1):1340-1347. 